\title{
Hot topics of thermal analysis
}

\section{New books on glass thermophysical research and open-access web site <Thermotics.eu>}

\author{
Jaroslav Šesták • Peter Šimon • Pavel Holba
}

Received: 26 July 2013/ Accepted: 26 July 2013/Published online: 29 August 2013

(C) Akadémiai Kiadó, Budapest, Hungary 2013

\section{Variability of constrained states and its impact on thermoanalytical measurements shaping the series "hot topics of thermal analysis"}

In the year 2000 Journal of thermal analysis and calorimetry published two key papers on the research lengthiness concerning noncrystalline states [1,2], which resulted from numerous articles dealing with the behavior of constrained states [3-6] and matching the modern appeal of glassines. This subject is factually younger that the detection of radioactivity and is still rapidly developing [7-13].

The idea of collecting broader viewpoints toward the formation and devitrification of glasses, particularly aimed at the confrontation of various aspects of descriptive theories, evaluative treatments, and applied technologies within the viewpoint of thermal analysis were a subject of journal special issues $[14,15]$. However, it is the first time that this subject is deeply treated in the book series $[16,17]$, the contents of which is survived herewith in more details.

\footnotetext{
J. Šesták · P. Holba

New Technology-Research Centre in the West Bohemian

Region, West Bohemian University, Universitní 8,

30114 Pilsen, Czech Republic

J. Šesták $(\bowtie)$

Section of Solid State Physics, Institute of Physics of the

Academy of Sciences, Cukrovarnicka 10,

16200 Prague, Czech Republic

e-mail: sestak@fzu.cz

P. Šimon

Faculty of Chemical and Food Technology, Slovak University of

Technology, Radlinského 9, 81237 Bratislava, Slovakia
}

Hot topics of thermal analysis, Volume 8 [16]

1. Introduction: Some Essential Attributes of Glassiness Regarding the Nature of Non-crystalline Solids (Hiroshi Suga)

2. Heat Capacity and Entropy Functions in Strong and Fragile Glass-Formers, Relative to Those of Disordering Crystalline Materials (C. Austen Angell)

3. Vibration Forms in the Vicinity of Glass Transition, Structural Changes and the Creation of Voids When Assuming the Role of Polarizability (Jaroslav Šesták, Bořivoj Hlaváček, Pavel Hubík, and Jiří J. Mareš)

4. Some Aspects of Vitrification, Amorphisation and Disordering and the Generated Extent of NanoCrystallinity (Jaroslav Šesták, Carlos A. Queiros, Miroslav Holeček, and Jiří J. Mareš)

5. Basic Role of Thermal Analysis in Polymer Physics (Adam L. Danch)

6. Phases of Amorphous, Crystalline, and Intermediate Order in Microphase and Nanophase Systems (Bernhard Wunderlich)

7. Thermal Portrayal of Phase Separation in Polymers Producing Nanophase Separated Materials (Ivan Krakovský and Yuko Ikeda)

8. Solid Forms of Pharmaceutical Molecules (Bohumil Kratochvíl)

9. Chalcogenide Glasses Selected as a Model Systém for Studying Thermal Properties (Zdeněk Černošek, Eva Černošková, and Jana Holubová)

10. Viscosity Measurements Applied to Chalcogenide Glass-Forming Systems (Petr Košt'ál, Jana Shánělová, and Jiří Málek)

11. Thermal Properties and Related Structural Study of Oxide Glasses (Marek Liška and Mária Chromčíková) 
12. Oxide Glass Structure, Non-bridging Oxygen and Feasible Magnetic Properties due to the Addition of $\mathrm{Fe} / \mathrm{Mn}$ Oxides (Jaroslav Šesták, Marek Liška, and Pavel Hubík)

13. New Approach to Viscosity of Glasses (Isak Avramov)

14. Transport Constitutive Relations, Quantum Diffusion and Periodic Reactions (Jiří J. Mareš, Jaroslav Šesták, and Pavel Hubík)

15. In-Situ Investigation of the Fast Lattice Recovery during Electropulse Treatment of Heavily Cold Drawn Nanocrystalline Ni-Ti Wires (Petr Šittner, Jan Pilch, Benoit Malard, Remi Delville, and Caroline Curfs)

16. Emanation Thermal Analysis as a Method for Diffusion Structural Diagnostics of Zircon and Brannerite Minerals (Vladimír Balek, Iraida M. Bountseva, and Igor von Beckman)

17. Scanning Transitiometry and Its Application in Petroleum Industry and in Polymer and Food Science (Jean-Pierre E. Grolier)

18. Constrained States Occurring in Plants Cryo-Processing and the Role of Biological Glasses (Jiří Zámečník and Jaroslav Šesták)

19. Thermophysical Properties of Natural Glasses at the Extremes of the Thermal History Profile (Paul Thomas, Jaroslav Šesták, Klaus Heide, Ekkehard Füglein, and Peter Šimon)

20. Hotness Manifold, Phenomenological Temperature and Other Related Concepts of Thermal Physics (Jiří J. Mareš)

21. Historical Roots and Development of Thermal Analysis and Calorimetry (Jaroslav Šesták, Pavel Hubík, and Jiří J. Mareš)

Hot topics of thermal analysis, Volume 9 [17]

1. Some Fundamental and Historical Aspects of Phenomenological Kinetics in the Solid State Studied by Thermal Analysis (Nobuyoshi Koga, Jaroslav Šesták, and Peter Šimon)

2. Equilibrium Background of Processes Initiated by Heating and Ehrenfest's Classification of Phase Transitions (Pavel Holba)

3. Crystal Defects and Nonstoichiometry Contributions to Heat Capacity of Solids (Pavel Holba and David Sedmidubský)

4. Forty Years of the Turnbull Reduced Glass Transition Temperature and Hruby Glass-Forming Coefficient and Their Current Perception (Ana KozmidisPetrovic and Jaroslav Šesták)
5. Heat Transfer and Phase Transition in DTA Experiments (Pavel Holba, Jaroslav Šesták, and David Sedmidubský)

6. Determination of the Glass Transition by DSC: A Comparison of Conventional and Dynamic Techniques (John M. Hutchinson)

7. Structural Relaxation and Viscosity Behavior in Supercooled Liquids at the Glass Transition (Jiří Málek and Roman Svoboda)

8. Kinetics of Structural Relaxation in Glasses (Emília Illeková)

9. Kinetics of Crystal Nucleation in Closed Systems (Zdeněk Kožǐšek, Pavel Demo, and Alexey Sveshnikov)

10. Influence of Preliminary Nucleation on the Physicogeometric Kinetics of Glass Crystallization (Nobuyoshi Koga and Jaroslav Šesták)

11. Application of Isoconversional Methods for the Processes Occurring in Glassy and Amorphous Materials (Peter Šimon and Paul S. Thomas)

12. Fractals in Solid-State Processes (Peter Šimon, Oldřich Zmeškal, and Jaroslav Šesták)

13. Crystallization of Metallic Micro-, Nano-, and NonCrystalline Alloys (Emília Illeková and Jaroslav Šesták)

14. Crystallization Kinetics in Amorphous and Glassy Materials (Jiří Málek and Jana Shánělová)

15. Comments on DTA Methods for Estimation of Crystal Nucleation Rates in Glass-Forming Melts (Vladimir M. Fokin, Aluısio A. Cabral, Raphael M.C. Reis, and Edgar D. Zanotto)

16. Nonparametric Kinetic Methodsm (Julia Sempere, Rosa Nomen, Eduard Serra, and Bernat Sempere)

17. Electron Transport Studies of Disorder and Dimensionality in Nano-Crystalline Diamond (Pavel Hubík and Jiří J. Mareš)

18. Controlled Nucleation and Crystallization for Nanoparticle Synthesis (Isak Avramov and Christian Rüssel)

19. Nucleation on Strongly Curved Surfaces of Nanofibers (Pavel Demo, Alexey Sveshnikov, and Zdeněk Kožíšek)

20. Thermal Analysis of Waste Glass Batches: Effect of Batch Makeup on Gas-Evolving Reactions (David A. Pierce, Pavel Hrma, and José Marcial)

21. Amorphous Inorganic Polysialates: Geopolymeric Composites and the Bioactivity of Hydroxyl Groups (Jaroslav Šesták, Nobuyoshi Koga, Peter Šimon, Bronislav Foller, Pavel Roubíček, and Nae-Lih Wu)

22. Oxide Superconductors as Model Systems for Studying Phase Relations, Stoichiometry, Reaction Kinetics, and Unconventional Glass Formability (Takayuki Komatsu and Jaroslav Šesták) 


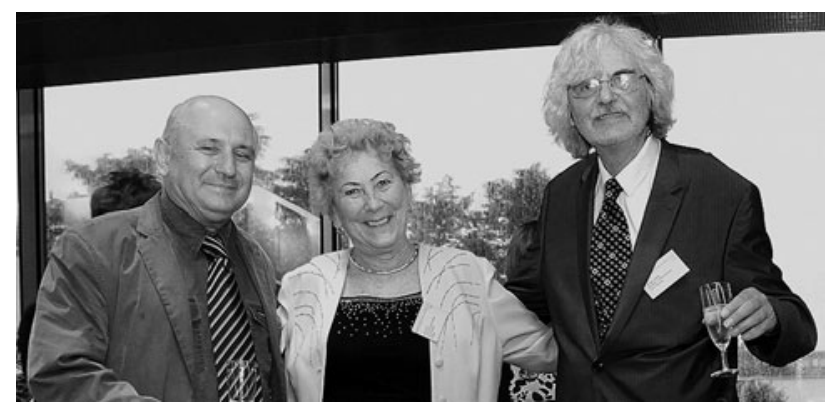

The second book, Vol. 9 was officially christened during the 4th Joint Czech-Hungarian-Polish-Slovak International Thermoanalytical Conference in Pardubice, June 2013, by the Series Editor and the ChiefEditor of JTAC, Prof. Judit Simon, (in the middle of key authors and book editors, Prof. P. Šimon and Prof. J. Šesták)

\section{A new open-access web site portal covering an extended range of thermophysical studies}

Newly launched open-access web site portal is proposed to provide a service to a wider community of scientists in the various branches of thermal science including thermodynamics, thermochemistry, thermometry, thermal analysis, thermal physics, calorimetry as well as heat transfer problems (thermokinetics). In 1837, English polymath, scientists, priest, philosopher, theologian, and historian of science William Whewell (1794-1866) professor of Cambridge University, coined the word "thermotics" in his book [27], mentioning the part "History of Thermotics and Atmology," by using the following sentence: "I employ the term Thermotics to include all the doctrines respecting Heat, which have hitherto been established on proper scientific grounds." In 1967, American physical chemist Ralph Tykodi (1925-2009) made an attempt to revive the term thermotics [25, 26]. His aim, however, was to revive or redress the term thermotics to be a science composed of three sub-branches: thermo-statics, that pertaining to the classical equilibrium aspects of heat; thermo-dynamics, that pertaining to those aspects for which time variation is important; and thermo-steadics, that pertaining to aspects that are temporally steady or stationary. Our attempt to revive the term thermotics was born at searching for an English equivalent of the Czech word "Teplozpyt" (Wärmeforschung, Теплоиспытание, Thermoscopy, Recherche de chaleur). Our understanding of this Czech word is similar to the conception of W. Wheller, who included into thermotics the "doctrines" of heat transfer and as well as "doctrines" of specific and latent heat (as accompanied to phase transitions), but extended mainly to the wide field of contemporary thermodynamics (including sub-branches proposed by R. Tykodi) and to the theory and practice of the various calorimetric and thermoanalytical methods and to the processing of their resulting measurement data. The portal <www.thermotics.eu $>$ will present an assortment of easy downloadable contributions from historical and aged papers to recent publication (even those unaccepted by journals), books, reports, lectures, news, and societal information (photos including historical records, newscast, and events), etc. <thermotics.eu $>$ should become a useful aid to the thermoanalytical venture depending on the cooperation and support of all. In the meantime the portal is linked with a personal web site $<$ www.fzu.cz/ $\sim$ sestak $>$ where several full-text free-downloadable book are available, such as:

- Thermodynamic applications concerning constrained states: Thermodynamic history, kinetic diagrams, glasses, phases characterization. Internal Report Book by the Institute of Physics (Academy of Sciences), 310 pp, 5 chapters, FZU, Prague 1990.

- Special Materials and Modern Technologies: processing theory, single-crystal-growth, organic semiconductors, magnetics, energy conversion; $688 \mathrm{pp}$ in Czech, 12 multipart chapters, Academia, Praha 1993.

- Heat, thermal analysis and society, Nucleus 2004, 380 pp, 20 chapters (ISBN 80-86225-54-2).

- Abstract Thermodynamics: states, manipulation, space and special structures, $174 \mathrm{pp}, 6$ chapters by OPS Nymburk, Pilzen 2006 (ISBN 80-239-6075-X).

- Thermal physics of structure of crystalline and noncrystalline materials, Pardubice 2008, 345 pp in Czech (ISBN 978-80-7395-023-1).

- Some thermodynamic, structural and behavioral aspects of materials accentuating noncrystalline states, OPS Plzeň 2009 with 610 pp, 28 chapters (ISBN 978-80-87269-06-0) and second addition 2011 (ISBN 978-80-87269-20-6).

- Selected topics of textile and material science, LiberecPlzeň 2011, 404 pp, 31 chapters, (ISBN 978-80-2610062-1).

Acknowledgements The results were developed within the CENTEM project, reg. no. CZ.1.05/2.1.00/03.0088 that is co-funded from the ERDF within the OP RDI program of the Ministry of Education, Youth and Sports. The authors feel also indebted to their scientific friends and coworkers: Sonia Ojo (Springer Publishing House, London), Judit Simon (University of Technology and Economy, Budapest), Pavel Hubik and Jiri J. Mares (Institute of Physics, AVCR, Praha) and Bronislav Foller (New Technology Research Centre, ZCU, Plzen). 


\section{References}

1. Šesták J. Miracle of reinforced states of matter: glasses—old and new structures for the third millennium. J Therm Anal Calorim. 2000;61:305.

2. Suga $H$. Propects of material science: from crystalline to amorphous solids. J Therm Anal Calorim. 2000;60:957.

3. Zachariesen WH. Atomic arrangement in glass. J Am Ceram Soc. 1932;54:3841.

4. Kauzmann W. Nature of the glassy state and the behavior of liquids at lower temperatures. Chem Rev. 1948;43:1.

5. Gibbs JH, DiMarzio EA. Nature of the glass transition and the glassy state. J Chem Phys. 1958;28:373-83.

6. Turnbull D. Under what conditions can a glass be formed? Contemp Phys. 1969;10:473-88.

7. Suga H, Seki S. Frozen-in states of orientational and positional disorder in molecular solids. Faraday Discuss Chem Soc. 1980;69:221-40.

8. Greaves GN, Sen S. Inorganic glasses, glass-forming liquids and amorphizing solids. Adv Phys. 2007;56:1-166.

9. Wunderlich B. Glass transition as a key to identifying solid phases. J Appl Polym Sci. 2007;105:49-59.

10. Gutzow I, Pascova R, Schmelzer JWP. Glass transition behavior: a generic phenomenological approach. Int J Appl Glass Sci. 2010;1:221-36.

11. Queiroz C, Šesták J. Aspects of the non-crystalline state. Phys Chem Glasses. 2010;51:165-72.

12. Biroli G, Garrahan JP. Perspective: the glass transition. J Chem Phys. 2013;138:12A301.

13. Hutchinson JM. Determination of the glass transition temperature: methods correlation and structural heterogeneity. J Therm Anal Calorim. 2009;98:579-89.

14. Kozmidis-Petrovic A, Šesták J. Forty years of the Hrubý glassforming coefficient via DTA when comparing other criteria in relation to the glass stability and vitrification ability. $\mathrm{J}$ Therm Anal Calorim. 2012;101:997-8.

15. Sesták $J$ (Ed) Vitrification, transformation and crystallization of glasses. Thermochimica Acta, Vol. 280/281, Elsevier, Amsterdam; 1996.
16. Schick C, Höhne CW (Eds) Interplay between nucleation, crystallization and the glass transition. Thermochimica Acta, Vol. 503, Elsevier, Amsterdam; 2011.

17. Šesták J, Mareš JJ, Hubík P (Eds) Glassy, amorphous and nanocrystalline materials: thermal physics, analysis, structure and properties, Springer, Dordrecht; 2010 (ISBN 978-90-481-28815).

18. Šesták J, Šimon P (Eds) Thermal analysis of micro, nano- and non-crystalline materials: transformation, crystallization, kinetics and thermodynamics, Springer, Dordrecht; 2013 (ISBN 978-90481-3149-5).

19. Šesták J. Citation records and some forgotten anniversaries in thermal analysis. J Therm Anal Calorim. 2012;108:511-8.

20. Fiala J, Šesták J. Databases in materials science. Contemporary state and future. J Therm Anal Calorim. 2000;60:1101-10.

21. Šesták J. Thermal science and analysis: history, terminology, development and the role of personalities. J Therm Anal Calorim. 2013;. doi:10.1007/s10973-012-2848-7 (in print).

22. Holba P, Šesták J. Czechoslovak footprints in the development of methods of thermometry, calorimetry and thermal analysis. Ceram-Silik. 2012;56:159-67.

23. Proks I. Evaluation of the knowledge of phase equilibria, first chapter. In: Chvoj Z, Šesták J, Tř́ska A, editors. Kinetic phase diagrams. Amsterdam: Elsevier; 1991

24. Proks I. The whole is simpler than its parts: chapters from the history of exact sciences. Bratislava: Veda-Slovak Academy of Sciences; 2012.

25. Bird Golding. Two chapters on thermotics in book: elements of natural philosophy - the study of the physical sciences. London: John Churchill; 1839.

26. Tykodi RJ. Thermodynamics of steady state. New York: MacMillan; 1967.

27. Tykodi RJ. Correspondence: thermodynamics-thermotics as the name of the game. Ind Eng Chem. 1968;60:22.

28. Whewell W. History of the inductive sciences, from the earliest to the present times, London. West Strand: John W. Parker; 1837. 